\title{
WŁASNOŚĆ WÓD W PRAWIE POLSKIM
}

\section{OWNERSHIP OF WATER IN THE POLISH LAW}

\section{STRESZCZENIE}

Celem tego opracowania jest scharakteryzowanie własności wód, wskazanie jej istotnych cech i elementów, szczególnie w kontekście prawa własności w prawie cywilnym. Analiza będzie także obejmować wykonywanie tego prawa, jak i jego nabywanie. Nie bez znaczenia pozostają również kwestie uprawnień, ale i obowiązków właściciela wód.

\section{Słowa kluczowe}

Ochrona wód, własność wód, właściciel wód.

* Prof. dr hab., kierownik Katedry Prawa Ochrony Środowiska WPiA UMK w Toruniu, radca prawny. 


\begin{abstract}
The aim of this study is to characterize the ownership of waters and to indicate its essential features and components, particularly in the context of property rights in civil law. The analysis will also include the exercise of this right, as well as its acquisition. Not without significance are also issue of the entitlements and responsibilities of the owner of the waters
\end{abstract}

\title{
Keywords
}

Water protection, ownership of waters, the owner of waters.

Zagadnienie własności wód było przedmiotem zainteresowania doktryny jeszcze pod rządami poprzednio obowiązujących aktów prawnych z zakresu prawa wodnego. Wskazywano na jego specyfikę i oderwanie od koncepcji własności rzeczy wypracowanej w prawie cywilnym. Zwracano też uwagę na to, że woda nie jest rzeczą w rozumieniu prawa cywilnego i nie może być przedmiotem stosunków cywilnoprawnych. Dorobek jurysprudencji w tym zakresie jest znaczny, o czym będzie jeszcze mowa niżej.

W pełni uwzględniając wypracowane dotychczas koncepcje i kierunki badań, należy jednak poddać problematykę własności wód nowym badaniom naukowym, a powodów do tego jest kilka. Za podstawową przyczynę należy uznać zmiany w konstrukcji systemu prawnego, zapoczątkowane na przełomie lat 80. i 90. Idea demokratycznego państwa prawa spowodowała zdefiniowanie na nowo interesu publicznego i w dalszej konsekwencji zmianę zadań, struktur i kompetencji organów administracji publicznej. Zmianie uległa także koncepcja państwa - Skarbu Państwa i jego uczestnictwa w obrocie prawnym. Kolejną inspiracją do badań nad prawem własności wód jest redefinicja pojęcia własności i przywrócenie jej właściwego miejsca w systemie prawnym. Dotyczy to przede wszystkim docenienia znaczenia własności prywatnej, zrównania wszystkich rodzajów własności i przyznania im jednolitej i należytej ochrony prawnej. Inspiracji do analizy prawa własności należy też poszukiwać w prawodawstwie europejskim, które stało się 
częścią polskiego porządku prawnego lub też ten porządek determinuje.

Wreszcie znaczenie ma uchwalenie w dniu 18 lipca $2001 \mathrm{r}$. nowej ustawy Prawa wodne ${ }^{1}$, który to akt prawny wprawdzie korzysta $\mathrm{z}$ rozwiązań przyjętych $\mathrm{w}$ poprzednich aktach prawnych, jednak zachowuje swoje specyficzne rozwiązania.

Te okoliczności przemawiają za tym, aby konstrukcji prawa własności wód przyjrzeć się od nowa, uwzględniając współczesne uwarunkowania i determinanty.

Celem tego opracowania jest scharakteryzowanie własności wód, wskazanie jej istotnych cech i elementów, szczególnie w kontekście prawa własności w prawie cywilnym. Analiza będzie także obejmować wykonywanie tego prawa, jak i jego nabywanie. Nie bez znaczenia pozostają również kwestie uprawnień, ale i obowiązków właściciela wód.

Rozpoczynając analizę konstrukcji własności wód, należy zauważyć, że w zasadzie odmawia się jej cywilnoprawnego charakteru ${ }^{2}$. Podstawowym argumentem $\mathrm{w}$ piśmiennictwie było to, że woda nie jest rzeczą z uwagi na to, że nie jest przedmiotem materialnym, który cechowałaby samoistność. Badano także związki rzeczowo prawne pomiędzy gruntem, na którym woda się znajduje, a samą wodą, co kierowało uwagę badaczy w stronę problematyki części składowej nieruchomości gruntowej.

W nowszym piśmiennictwie utrzymano krytyczną linię co do odmowy uznania własności wód za własność w rozumieniu prawa cywilnego. Piotr Machnikowski zauważa, że „Nie stanowią zatem własności w rozumieniu kodeksowym prawa bezwzględne i możliwie pełne pod względem treści, mające za przedmiot dobra materialne inne niż rzeczy. Dotyczy to w szczególności »własności« wód [...]; »własności« złóż kopalin nie-

1 Dz.U. z 2012, poz. 145, dalej cyt.: Prawo wodne.

2 Por. chociażby T. Dybowski, Własność wód, [w:] S. M. Grzybowski (red.), Zagadnienia cywilistyczne prawa wodnego, Warszawa 1957, s. 109; A. Agopszowicz, Własność wód, jej istota i charakter prawny, ZNUJ z 1974, z. 1, s. 25-39; S. Rudnicki, O własności wód, NP z 1982, z. 11-12, s. 78 i n.; E. Gniewek, W kwestii statusu prawno rzeczowego powierzchniowych wód płynących i wspótwystępujących elementów naturalnych środowiska wodnego, ZNUW XXI, s. 79. 
stanowiących części składowych gruntu [...]; »Własności« zwierząt [...]. W wymienionych przypadkach ustawodawca, mniej lub bardziej wyraźnie, konstruuje prawa do przedmiotów materialnych podobne do własności, czy to przez odesłanie do przepisów o własności [...] lub w ogóle o rzeczach [...], czy to przez samo użycie słowa »własność« w niewłaściwym znaczeniu $[\ldots]^{\prime \prime}$.

Jerzy Ignatowicz zauważył, że „[...] w języku prawniczym oraz poszczególnych aktach normatywnych termin «własność» jest też używany w znaczeniu poważnie odbiegającym od tej definicji [tj. definicji własności według art. $140 \mathrm{kc}$ - przyp. B.R.]. Mówi się np. o własności przemysłowej, o własności intelektualnej, własności wód czy własności górniczej, choć chodzi tu nie o prawo do rzeczy, a do dóbr innego rodzaju (osiągnięcia myśli ludzkiej, wody płynące i podziemne, złoża kopalin)"”.

Krytyka sformułowana w doktrynie prawa cywilnego co do cywilistycznego rozumienia pojęcia własności wód nie straciła na aktualności. Nadal bowiem wody nie mogą być uznane za rzeczy w rozumieniu prawa cywilnego i to właściwie przesądza o dalszym toku rozumowania i argumentowania. Co jednak istotne odmawia się uznania własności wód za własność w rozumieniu prawa cywilnego tylko z tego względu, że przedmiot tego prawa - wody powierzchniowe i podziemne - nie mają przymiotu rzeczy. Natomiast nie kwestionuje się używania pojęcia własności na oznaczenie więzi podmiotu z przedmiotem i uprawnień właściciela wody w stosunku do tejże wody.

Z drugiej jednak strony prawodawca polski pomimo tejże krytyki nadal posługuje się taką definicją własności wód w tekstach prawnych. Powstaje pytanie, dlaczego to robi i jak ową własność należy rozumieć.

Jan Szachułowicz zauważa, że „Prawo wodne wyodrębnia wodę jako przedmiot samodzielnych uregulowań, niezależnie od własności gruntu, ze względu na gospodarcze znaczenie wód

3 P. Machnikowski, [w:] T. Dybowski (red.), System Prawa Prywatnego, t. 3, Prawo rzeczowe, Warszawa 2003, s. 22.

4 J. Ignatowicz, [w:] J. Ignatowicz, K. Stefaniuk, Prawo rzeczowe, wyd. 4, Warszawa 2012, s. 44. 
płynących”5. Natomiast Jerzy Rotko zauważa, iż „Problematyka własności wód ma podstawowe znaczenie dla określenia zakresu praw i obowiązków związanych z wodami"6.

Na kwestię własności wód można zatem spojrzeć dwojako. Po pierwsze, należy zauważyć, że woda jest przedmiotem samodzielnych uregulowań normatywnych. Jest też przedmiotem samodzielnych stosunków prawnych, które cechuje specyfika zdeterminowana uznaniem wody za przedmiot samodzielnych uregulowań. W konsekwencji prawodawca nie tak stara się wtłoczyć kwestię wód w ramy prawa rzeczowego, ale odwrotnie, podporządkowuje klasyczne instytucje prawa cywilnego wodzie i jej statusowi prawnemu.

Po drugie, traktując wody jako przedmiot samodzielnych uregulowań i w konsekwencji samodzielnych stosunków prawnych, ustawodawca czyni to, mając na względzie uprawnienia i obowiązki związane z wodami. Owe uprawnienia i obowiązki są charakterystyczne dla prawa wodnego i nie podporządkowują się w pełni konwencji prawa cywilnego.

Samodzielność normatywna wód spowodowała przełamanie typowych konstrukcji prawa cywilnego, a przede wszystkim prawa własności, choć z drugiej strony warto zastanowić się, dlaczego pomimo owego przełamania prawodawca używa pojęcia własności, które ma już swoje ugruntowane znaczenie w prawie cywilnym.

W języku prawnym i prawniczym pojęcie własności jest wykorzystywane, pomimo iż nie wchodzi w grę typowy dla własności element, jakim jest istnienie rzeczy w rozumieniu art. 45 kc. Przykładem jest dział prawa cywilnego, czyli prawo własności intelektualnej. Pojęcie własności pojawia się w odniesieniu do wynalazków, znaków towarowych, oznaczeń topograficznych itd., które określa się pojęciem ogólnym własności przemysłowej. Zagadnienia te uregulowane są w ustawie z dnia 30 czerwca 2000 r. Prawo własności przemysłowej

5 J. Szachułowicz, Prawo wodne. Komentarz, wyd. 4, Warszawa 2010, s. 61.

6 J. Rotko, Podstawy prawne gospodarki wodnej, Wrocław 2006, s. 56.

Dz.U. z 2003 Nr 119, poz. 1117 ze zm. 
W piśmiennictwie wskazuje się, że „Użycie nazwy »własność« podkreśla analogię pomiędzy wymienionymi prawami a cywilnoprawną własnością dóbr materialnych, wyrażającą się zwłaszcza w majątkowym i bezwzględnym (skutecznym erga omnes) charakterze i treści praw na rzeczy (iura In Re) oraz uprawnień objętych własnością przemysłową. Analogia ta uzasadnia odpowiednie stosowanie do własności przemysłowej przepisów praw rzeczowego. Między własnością przemysłową a własnością cywilną zachodzą jednak również istotne różnice. Obok ontologicznych właściwości przedmiotów (dobra niematerialne - przedmioty materialne) dotyczą one przede wszystkim terytorialnego i czasowego ograniczenia własności przemysłowej"8.

Jak wynika z przedstawionych powyżej poglądów, kwestia posługiwania się pojęciem własności w odniesieniu do dóbr niematerialnych nie budzi wątpliwości, tym bardziej, że dobra takie również nie są rzeczami w rozumieniu prawa rzeczowego. Co istotne, pojęcie własności rzeczy nie oznacza tylko jakiejś konstrukcji sui iuris, ale własność w jej cywilistycznym ujęciu. Powstaje pytanie, dlaczego prawodawca uznał, że konstrukcja własności może być z powodzeniem wykorzystywana nawet w odniesieniu do dóbr niematerialnych, które nie są rzeczami? Andrzej Szewc i Gabriela Jyż zwrócili uwagę na charakter własności, która jest skuteczna wobec wszystkich. Dostrzegli też analogię w samej treści prawa własności, jak i w majątkowym charakterze własności. Te spostrzeżenia można z powodzeniem odnieść do własności wód. Decydujące znaczenie ma bezwzględny charakter prawa własności wód, które winno być skuteczne względem wszystkich. Podobne spostrzeżenia należy odnieść do majątkowego charakteru prawa własności. Wszak wody są przedmiotem gospodarowania, które samo w sobie zawiera majątkowe elementy. Wreszcie treść prawa własności, która obejmuje wszystkie uprawnienia właściciela, byleby nie naruszały one norm prawnych, zasad współżycia społecznego i społeczno-gospodarczego przeznaczenia prawa. W przypad-

8 A. Szewc, G. Jyż, Prawo własności przemysłowej, Warszawa 2003, s. 1-2. 
ku własności wód można też mówić o obowiązkach właścicieli tychże, o czym będzie jeszcze mowa niżej.

Powyższe rozważania dotyczące własności intelektualnej, a przede wszystkim własności przemysłowej mogą być przydatne dla zrozumienia własności wód. Decydujące znaczenie wydają się tu także mieć inne okoliczności niż przedmiot. Przedmiot takiego prawa przesuwany jest na plan dalszy. O zasadności wyeksponowania własności, jako prawa do dóbr niematerialnych lub do przedmiotów niebędących rzeczami, decydują zatem inne kryteria i to ważniejsze niż sam przedmiot, choć przez ten przedmiot silnie zdeterminowane.

Wydaje się, że o takim zachowaniu ustawodawcy zdecydowały dwie okoliczności. Tomasz Dybowski zauważa, że gospodarowanie wodami wiąże się z koniecznością wykonywania określonych uprawnień, ale również i obowiązków9

Rzymska koncepcja prawa własności eksponowała przede wszystkim uprawnienia przysługujące właścicielowi rzeczy. Współczesna koncepcja prawa własności nie ogranicza się jedynie do pozytywnego wymienienia uprawnień właściciela, ale punktem wyjścia jest stwierdzenie, że nie da się ich wszystkich wymienić enumeratywnie. Stąd też istotę prawa własności można oddać jedynie poprzez wskazanie nie tyle uprawnień, jakie składają się na to prawo, ale przez wskazanie granic wykonywania takiego prawa. Dlatego też na tle art. 140 kc formułuje się powszechnie aprobowany pogląd, że granice prawa własności określają przepisy prawa powszechnie obowiązującego, zasady współżycia społecznego i społeczno-gospodarcze przeznaczenie prawa.

Nie kontynuując rozważań na temat istoty własności, należy poprzestać na stwierdzeniu, że prawo to obejmuje w najszerszym zakresie zbiór poszczególnych uprawnień, które przysługują właścicielowi. Ich szczegółowy zakres ma już mniejsze znaczenie, istotne jest to, że prawo własności obejmuje najszerszy z możliwych zakresów uprawnień przysługujących określonemu podmiotowi.

9 T. Dybowski, Własność wód, [w:] S. M. Grzybowski (red.), Zagadnienia cywilistyczne prawa wodnego, Warszawa 1957, s. 109. 
Punktem wyjścia do dalszej analizy pojęcia własności wód jest stwierdzenie T. Dybowskiego, że na tę konstrukcję składa się określona grupa uprawnień i obowiązków. Ustawodawca miał i ma świadomość, że prawidłowe gospodarowanie wodami, które leży u podstaw prawa wodnego, wiąże się z koniecznością wykonywania określonych uprawnień, ale i obowiązków. Stąd też działania prawodawcy powinny zmierzać do tego, aby określić i wyeksponować więź łączącą właściciela wody z samą wodą.

Jak już wyżej wskazywano, w prawie rzymskim eksponowano przede wszystkim uprawnienia wynikające z prawa własności. One to absorbowały uwagę rzymskich jurystów. We współczesnej polskiej cywilistyce wskazuje się, że „Treść podmiotowego prawa własności, niezależnie od założeń ustrojowych i prawno-systemowych, jest określona przez sumę uprawnień przysługujących na podstawie prawa przedmiotowego właścicielowi w stosunku do rzeczy"10.

$\mathrm{Z}$ analizowanego punktu widzenia znaczenie ma to, że własność stanowi określona suma uprawnień właściciela. Tego typu założenie wiąże się, po pierwsze, z tym, że zwalnia ono prawodawcę z próby szczegółowego określenia, jakie to konkretne uprawnienia ma właściciel. Po drugie, stwarza domniemanie, iż właściciel działa zgodnie z prawem, jeśli co innego wyraźnie nie wynika z granic wyznaczonych dla prawa własności. Koncepcja domniemania uprawnień-kompetencji była już lansowana przez Waleriana Pańkę, który twierdził, że „istotę prawa własności najprościej, ale najpełniej wyraża idea domniemania kompetencji; domniemania leżącego po stronie właściciela, a odnoszącego się do ogółu zachowań względem określonej rzeczy (dobra)"11.

Wydaje się jednak, że ta koncepcja, tak atrakcyjna z punktu widzenia prawa cywilnego, w prawie wodnym nie odgrywa dużego znaczenia. Przede wszystkim należy dostrzec, że ustawodawca $\mathrm{w}$ prawie wodnym nie tyle eksponuje uprawnienia właściciela wód, ile ich obowiązki. Uprawnienia o tyle są przed-

10 S. Rudnicki, Własność nieruchomości, wyd. 3, Warszawa 2012, s. 18.

11 W. Pańko, O prawie własności i jego współczesnych funkcjach, Katowice 1984, s. 75-76. 
miotem regulacji prawa wodnego, o ile ma to służyć osiąganiu celów publicznych. Nieco odmiennie przedstawia się kwestia własności wód innych podmiotów niż podmioty publiczne. Przykładem przepisu regulującego uprawnienia właściciela wód jest art. 13 Prawa wodnego.

Istotną cechą własności wód jest to, że wiąże się ono ściśle z obowiązkami właściciela. Kwestią wymagającą analizy jest charakter prawny tego związku, a ściślej rzecz ujmując to, czy obowiązki te są wpisane w istotę prawa własności i stanowią jej integralną i nierozerwalną część, czy też są to jedynie pozytywne obowiązki obciążające właściciela wód. W piśmiennictwie z zakresu polskiego prawa cywilnego istnienie obowiązków po stronie właściciela, które są wpisane $\mathrm{w}$ istotę prawa własności, uznaje się za co najmniej dyskusyjne.

Wojciech J. Kocot zauważa, że „Trudno też podzielić pogląd, że własność to kompleksowy system nie tylko praw, lecz także pozytywnych obowiązków właściciela. Skoro własność uznaje się powszechnie za prawo podmiotowe, to nie może wynikać z niego dla właściciela obowiązek wykonywania jego prawa. Wszelkie pozytywne obowiązki właściciela obciążające go z mocy prawa [...] nie składają się na treść prawa własności, stanowiąc jedynie korelat tego prawa"12.

Nieco odmienny pogląd prezentuje Andrzej Stelmachowski, który stwierdza, iż „Można więc zaryzykować twierdzenie, że błędem byłoby dziś ujmowanie własności li tylko jako prawa podmiotowego. Własność jest raczej kompleksem praw i obowiązków. Nie jest to zresztą sytuacja prawna nieznana systemowi prawa cywilnego"13.

Nie podejmując się rozwiązania tego sporu, z całą pewnością należy stwierdzić, że w przypadku własności wód bez wątpienia istnieją obowiązki tegoż właściciela i to połączone z samą własnością. Pomimo ścisłego powiązania obowiązków właściciela wód z prawem własności należy jednak przyjąć, że obowiązki te nie stanowią o istocie prawa własności. Do wnio-

12 W. J. Kocot, [w:] A. Brzozowski, W. J. Kocot, W. Opalski, Prawo rzeczowe. Zarys wykładu, Warszawa 2012, s. 57-58.

13 A. Stelmachowski, Zarys teorii prawa cywilnego, Warszawa 1997, s. 206. 
sku takiego prowadzi wykładnia systemowa. Prawodawca bowiem wyraźnie oddziela prawo własności wód od obowiązków właściciela wód. To jednoznacznie rozstrzyga, że obowiązki nie stanowią istoty własności. W tym też zakresie pogląd W. J. Kocota należy w pełni podzielić, tym bardziej, że autor ten dostrzega istnienie obowiązków obciążających właściciela rzeczy, ale nie łączy ich z samą istotą własności.

Niemniej jednak eksponowanie obowiązków właściciela wód usprawiedliwia formowanie konstrukcji własności wód, obejmującej uprawnienia i ściśle z nimi powiązane obowiązki. Ustawodawca posłużył się tu konstrukcją własności z kilku powodów. Przede wszystkim chciał oddać szczególnego rodzaju więź, jaka łączy właściciela z przedmiotem tej własności ${ }^{14}$. Owa więź polega na najszerszym władztwie nad rzeczą. Odwołując się do własności, prawodawca uniknął także precyzyjnego wymieniania poszczególnych uprawnień. Wskazuje natomiast na najszersze władztwo właściciela wód nad tymi wodami. Szerokie ujmowanie władztwa nad wodami ma przede wszystkim służyć osiąganiu interesu publicznego, gdyż władztwo to przejawia się przede wszystkim w odniesieniu do wód płynących i pozostałych wód publicznych.

Jednocześnie w konsekwencji z własnością wód łączy on obowiązki właściciela wód, które wprawdzie o samej własności nie decydują, niemniej są ujmowane szeroko i precyzyjnie.

Analizując kwestie własności wód, nie sposób pominąć bardzo istotnych aspektów podmiotowych. Zakres podmiotowy stanowi o istocie własności wód, jako konstrukcji sui iuris. Podział podmiotowy własności wód przebiega według kilku kryteriów. Pierwsze z nich, mające charakter kryterium naturalnego, odwołuje się do podziału wód na wody powierzchniowe i wody podziemne. Te drugie mogą być przedmiotem własności Skarbu Państwa. Natomiast zakres podmiotowy tych pierwszych może być zróżnicowany.

Kolejnym kryterium jest również kryterium naturalne, według którego można podzielić wody powierzchniowe na

14 Celowo nie używam pojęcia z rzeczą z tego względu, że wodom należy odmówić przymiotu rzeczy. 
wody płynące i stojące. Także i to kryterium ma istotne znaczenie z punktu widzenia podmiotowego. Wody płynące mogą być przedmiotem własności wyłącznie Skarbu Państwa, podczas gdy zakres podmiotowy własności wód stojących może być zróżnicowany.

Wreszcie wody dzielą się już typowo według kryterium normatywnego na wody publiczne i wody niepubliczne, w zależności od tego, czy właścicielem jest podmiot publiczny, czy podmiot prywatny.

Analiza tych kryteriów pozwala na stwierdzenie, że Skarb Państwa jest jedynym właścicielem wód podziemnych i powierzchniowych wód płynących. Obok monopolistycznej własności Skarbu Państwa wyróżnia się także własność publiczną, która obejmuje własność Skarbu Państwa i innych podmiotów publicznych - jednostek samorządu terytorialnego.

Można dostrzec, że w konstrukcji własności wód dominuje własność podmiotów publicznych i jest to celowe działanie prawodawcy. Własność wód, przysługującą innym podmiotom, należy uznawać za wyjątek. W piśmiennictwie wypracowano pogląd, iż w istocie można wyróżnić trzy kategorie podmiotów, którym może przysługiwać własność wód - Skarb Państwa, który traktowany jest jako odrębna kategoria podmiotowa, inne niż Skarb Państwa osoby prawne, osoby fizyczne ${ }^{15}$.

Na uwagę zasługuje, pomijany w doktrynie problem, własności Skarbu Państwa. Własność ta ma przede wszystkim charakter monopolistyczny i to $\mathrm{w}$ dwóch ściśle ze sobą powiązanych wymiarach - po pierwsze, własność może przysługiwać tylko Skarbowi Państwa, po drugie, ma ona charakter niezbywalny.

Powstaje pytanie o motywy prawodawcy, który jednak uznał, że w przypadku wód powierzchniowych płynących i wód podziemnych konieczne jest zachowanie monopolu państwa. Co interesujące, prawodawca nawet nie zdecydował się na pozostawienie tychże wód w ogóle w rękach podmiotów publicznych, ale jedynie Skarbu Państwa.

15 Tak W. Radecki, [w:] J. Rotko (red.), Komentarz, s. 52; J. Szachułowicz, Komentarz, s. 56. 
U podstaw takiego rozwiązania leży kilka okoliczności. Przede wszystkim należy zwrócić uwagę na znaczenie wód podziemnych i powierzchniowych wód płynących z punktu widzenia zasobów strategicznych. Jak stanowi art. 1 ustawy z dnia 6 lipca 2001 r. o zachowaniu narodowego charakteru strategicznych zasobów naturalnych kraju ${ }^{16}$ :

Do strategicznych zasobów naturalnych kraju zalicza się:

1) wody podziemne oraz wody powierzchniowe w ciekach naturalnych i w źródłach, z których te cieki biorą początek, w kanałach, w jeziorach i zbiornikach wodnych o ciągłym dopływie w rozumieniu ustawy z dnia 18 lipca 2001 r. - Prawo wodne (Dz.U. Nr 115, poz. 1229 i Nr 154, poz. 1803, z 2002 r. Nr 113, poz. 984, Nr 130, poz. 1112, Nr 233, poz. 1957 i Nr 238, poz. 2022 oraz z 2003 r. Nr 80, poz. 717),

2) wody polskich obszarów morskich wraz $z$ pasmem nadbrzeżnym i ich naturalnymi zasobami żywymi i mineralnymi, a także zasobami naturalnymi dna i wnętrza ziemi znajdującego się w granicach tych obszarów w rozumieniu ustawy z dnia 21 marca 1991 r. o obszarach morskich Rzeczypospolitej Polskiej i administracji morskiej (Dz.U. Nr 32, poz. 131, z 1994 r. Nr 27, poz. 96, z 1995 r. Nr 7, poz. 31 i Nr 47, poz. 243, z 1996 r. Nr 34, poz. 145, z 1997 r. Nr 111, poz. 726, z 1999 r. Nr 70, poz. 778 oraz z 2000 r. Nr 120, poz. 1268 i Nr 122, poz. 1321),

3) lasy państwowe,

4) złoża kopalin niestanowiące części składowych nieruchomości gruntowej w rozumieniu ustawy z dnia 4 lutego 1994 r. - Prawo geologiczne i górnicze (Dz.U. Nr 27, poz. 96, z 1996 r. Nr 106, poz. 496, z 1997 r. Nr 88, poz. 554, Nr 111, poz. 726 i Nr 133, poz. 885, z 1998 r. Nr 106, poz. 668 oraz z 2000 r. Nr 109, poz. 1157 i Nr 120, poz. 1268),

5) zasoby przyrodnicze parków narodowych.

W myśl art. 3 tejże ustawy „Gospodarowanie strategicznymi zasobami naturalnymi jest prowadzone zgodnie $\mathrm{z}$ zasadą zrównoważonego rozwoju w interesie dobra ogólnego". Cel

16 Dz.U. Nr 97, poz. 1051 ze zm., dalej jako ustawa o zachowaniu zasobów strategicznych. 
wskazany w tym przepisie może być osiągnięty jedynie w sytuacji zachowania normatywie gwarantowanego monopolu Skarbu Państwa.

Po drugie, dla właściwego gospodarowania wodami znaczące jest to, aby znajdowały się one we władaniu jednego podmiotu, w tym wypadku Skarbu Państwa. Argument ten wzmacnia art. 11 Prawa wodnego, mówiący o tym, jakie organy wykonują prawa właścicielskie Skarbu Państwa, a więc podejmują czynności zmierzające do właściwego gospodarowania wodami.

Po trzecie, tylko Skarb Państwa jako jedyny podmiot publiczny gwarantuje wykonywanie prawa własności, a także wykonywanie obowiązków jednolicie na obszarze całego państwa. Tylko bowiem on obejmuje zakresem swoich kompetencji obszar całego państwa. Może więc wykonywać uprawnienia i obowiązki w stosunku do takich wód, które nie poddają się w zasadzie granicom. Stąd też normatywnie określony monopol Skarbu Państwa jest ze wszech miar uzasadniony.

W przypadku własności pozostałych wód nie jest już konieczny monopol Skarbu Państwa, stąd też prawodawca dopuszcza własność innych osób prawnych, a nawet własność wód osób fizycznych. Podkreślić jednak należy, że znaczenie ma podział własności wód na własność publiczną i własność niepubliczną, który nie pokrywa się z podziałem własności na własność Skarbu Państwa, innych osób prawnych i osób fizycznych. O ile podział własności według tego drugiego kryterium wiązał się z koniecznością istnienia monopolu po stronie Skarbu Państwa, o tyle ten drugi ma znaczenie z punktu widzenia udostępniania wód.

Granice udostępniania wód w ramach powszechnego korzystania z wód wyznacza art. 34 ust. 1 Prawa wodnego, stanowiący, iż „1. Każdemu przysługuje prawo do powszechnego korzystania ze śródlądowych powierzchniowych wód publicznych, morskich wód wewnętrznych, wraz z morskimi wodami wewnętrznymi Zatoki Gdańskiej, i z wód morza terytorialnego, jeżeli przepisy nie stanowią inaczej". 
Podział wód na wody publiczne, a więc stanowiące własność Skarbu Państwa i jednostek samorządu terytorialnego, oraz wody niepubliczne odgrywa zatem istotną rolę dla kształtowania podmiotowego prawa każdego do korzystania z wód. Jak zauważa Katarzyna I. Kobus-Ogrodniczak, „Jest ono publicznym prawem podmiotowym, które przysługuje każdemu, to znaczy każdej osobie fizycznej przebywającej na terytorium Polski bez względu na obywatelstwo, wiek czy zdolność do czynności prawnych"17. Prawo to obejmuje ex definitione śródlądowe, powierzchniowe wody publiczne oraz wskazane w tym przepisie wprost wody morskie. W ten sposób prawodawca zezwala na korzystanie z wód podmiotów publicznych w zakresie ograniczonym tylko przepisami ustawy.

Tymczasem śródlądowe powierzchniowe wody niepubliczne co do zasady nie są objęte powszechnym prawem korzystaniem z nich. Możliwość objęcia ich tymże prawem może wynikać jedynie z uchwały rady powiatu, podejmowanej na podstawie art. 35 Prawa wodnego. Przepis ten stanowi, że:

1. Rada powiatu może, w drodze uchwały, w celu zaspokajania niezbędnych potrzeb społecznych wprowadzić powszechne korzystanie, służące zaspokajaniu potrzeb osobistych, gospodarstwa domowego lub rolnego, z wód powierzchniowych innych niż wymienione $\mathrm{w}$ art. 34 ust. 1, ustalając jednocześnie dopuszczalny zakres tego korzystania.

2. W przypadku, o którym mowa $\mathrm{w}$ ust. 1, właścicielowi wody przysługuje z budżetu powiatu odszkodowanie na warunkach określonych w ustawie.

Jest to jednak wyjątek od zasady ochrony własności wód niepublicznych.

Powszechne korzystanie $\mathrm{z}$ wód nie obejmuje wód podziemnych. Korzystanie z wód podziemnych reguluje w art. 36 Prawa wodnego, w ramach tzw. zwykłego korzystania z wód. Przepis ten stanowi, że:

17 K. I. Kobus-Ogrodniczak, Korzystanie z wód - problemy prawne, Toruń 2011, s. 51. 
1. Właścicielowi gruntu przysługuje prawo do zwykłego korzystania $\mathrm{z}$ wód stanowiących jego własność oraz z wody podziemnej znajdującej się w jego gruncie; prawo to nie stanowi prawa do wykonywania urządzeń wodnych bez wymaganego pozwolenia wodnoprawnego.

2. Zwykłe korzystanie z wód służy zaspokojeniu potrzeb własnego gospodarstwa domowego oraz gospodarstwa rolnego, z zastrzeżeniem ust. 3.

3. Nie stanowi zwykłego korzystania z wód:

1) nawadnianie gruntów lub upraw wodą podziemną za pomocą deszczowni;

2) pobór wody powierzchniowej lub podziemnej w ilości większej niż $5 \mathrm{~m}^{3}$ na dobę;

3) korzystanie z wód na potrzeby działalności gospodarczej;

4) rolnicze wykorzystanie ścieków lub wprowadzanie do wód lub do ziemi oczyszczonych ścieków, jeżeli ich łączna ilość jest większa niż $5 \mathrm{~m}^{3}$ na dobę.

Odmiennie ustawodawca uregulował status własności wód stojących. Nie kreuje on odrębnego, czy szczególnego prawa własności, poprzestając na przyjęciu zasady, że kto jest właścicielem gruntu pod wodami, jest właścicielem wód stojących. Normatywnym wyrazem tej zasady jest art. 12 Prawa wodnego, stanowiący, iż „, 1 . Wody stojące oraz wody w rowach, znajdujące się w granicach nieruchomości gruntowej, stanowią własność właściciela tej nieruchomości".

W stosunku do wód w rowach i wód stojących zastosowanie znajdzie więc zasada superficies solo cedit $^{18}$. Jest to więc typowa konstrukcja prawa cywilnego. J. Szachułowicz słusznie zauważył, że „Własność wody stojącej oraz własność wody w rowach jest określana według zasady - czyją własność stanowi grunt, ten jest właścicielem wody. Jest to odwrotność zasady obowiązującej przy wodach powierzchniowych płynących. Wody te stanowią własność publiczną i własność wody przekłada się na własność gruntu pod wodą [...]. Ta relacja zachodząca pomiędzy gruntem a wodą płynącą wynika z zasady, że

18 Tak też M. Kałużny, Komentarz, s. 81. 
woda płynąca w regulacji ustawowej stanowi odrębny od gruntu przedmiot własności"19.

Nie oznacza to jednak, że własność wód stojących i wód $\mathrm{w}$ rowach jest typową własnością $\mathrm{w}$ rozumieniu prawa wodnego. Nadal aktualne pozostają zarzuty co do tego, czy woda ma przymiot rzeczy. Poza tym obowiązki właścicieli wód obciążają także i tych, którzy są właścicielami wód stojących i wód w rowach, a jak wyżej stwierdzono, obowiązki są istotowo powiązane z uprawnieniami właściciela.

$\mathrm{Z}$ analizowanego punktu widzenia znaczenie ma także treść i wykonywanie własności, a także jej nabycie i utrata. Tym zagadnieniom będą poświęcone dalsze rozważania.

Treść i wykonywanie prawa własności są ze sobą powiązane. Treść własności obejmuje ogół uprawnień, jakie przysługują właścicielowi, oraz ściśle z nimi powiązanych obowiązków. Natomiast wykonywanie własności wiąże się zarówno z wykonywaniem uprawnień, jak i obowiązków, obciążających właściciela.

Ustawodawca nie określił, jakie uprawnienia składają się na własność wód. Należy jedynie przypomnieć, że chodzi o skumulowanie w ramach jednego, najszerszego prawa do wód, ogółu tychże uprawnień. Można więc przyjąć, że właścicielowi wód przysługują najszerzej rozumiane uprawnienia związane z wodami. Niemniej jednak można zrekonstruować niektóre $\mathrm{z}$ nich.

Za podstawowe uprawnienie właściciela wody należy uznać eksponowane w prawie wodnym uprawnienie do pobierania pożytków. Jest ono szeroko uregulowane w art. 13 Prawa wodnego. Przy czym uprawnienie to jest szeroko rozumiane, gdyż obejmuje i pożytki naturalne, i pożytki cywilne, a nawet i pożytki prawa. Wyeksponowanie uprawnienia do pobierania pożytków wiąże się z leżącą $\mathrm{w}$ centrum prawa wodnego gospodarką wodami, której istotnym elementem jest ich prawidłowe zagospodarowanie i wykorzystanie.

Podstawowym obowiązkiem właściciela każdej wody jest obowiązek jej utrzymania. Wojciech Radecki stwierdza jednak

\footnotetext{
19 J. Szachułowicz, Komentarz, s. 66.
} 
trafnie, iż: „Wprawdzie nie ma wzmianki, że chodzi o utrzymywanie wód »W należytym stanie«, ale takie uzupełnienie jest oczywiste choćby w świetle art. 193 ust. 1 pkt 1 Prawa wodnego, który za wykroczenie uznaje właśnie nieutrzymywanie wód (lub urządzeń wodnych) w należytym stanie"20. Ten ogólnie określony w art. 21 ust. 1 Prawa wodnego obowiązek jest przez ustawodawcę doprecyzowany, na konkretnie jakich działaniach i zaniechaniach utrzymywanie wód polega. Można jednak sformułować tu podobną ocenę jak w przypadku uprawnień. Jeden ogólnie sformułowany obowiązek, doprecyzowany w innych, dalszych przepisach ustawy Praw wodne, świadczy o wyeksponowaniu przez ustawodawcę tego elementu, który ma znaczenie z punktu widzenia gospodarowania wodami. Ich utrzymywanie, i to w należytym stanie, jest podstawą prawidłowo prowadzonej gospodarki wodnej.

Wykonywanie własności regulowane jest częściowo przepisami prawa wodnego. Dotyczy to przede wszystkim wód płynących. Przykładem takiej regulacji jest chociażby art. 11 Prawa wodnego i art. 12 ust. 2 określający, kto w imieniu Skarbu Państwa wykonuje prawa właścicielskie. Wykonywanie własności powierzchniowych wód płynących charakteryzuje się znaczną jego reglamentacją i regulacjami normatywnymi. Jednak takie rozwiązanie jest w pełni zasadne, gdyż wykonywanie własności tychże wód następuje w interesie publicznym. Stąd też wykonywanie uprawnień jest precyzyjnie określone i w art. 11 Prawa wodnego i w art. 13 ust. 2 i n. Prawa wodnego i wreszcie w art. 14a Prawa wodnego, choć $\mathrm{w}$ tym drugim przypadku w grę wchodzi gospodarowanie gruntami pod powierzchniowymi wodami płynącymi.

Natomiast w przypadku do pozostałych wód powierzchniowych wykonywanie prawa ich własności nie cechuje się już takim poziomem reglamentacji i ustawodawca pozostawia woli właściciela, jak je będzie wykonywał. Czyni to jednak w swoim interesie, a nie interesie publicznym, stąd też mniejszy zakres reglamentacji.

20 W. Radecki, [w:] J. Rotko (red.), Komentarz, s. 79. 
Ostatnim zagadnieniem, które wymaga analizy, jest kwestia nabywania własności wód. Jak wynika z art. 10 ustęp 1 Prawa wodnego płynące wody publiczne nie podlegają obrotowi cywilnoprawnemu, chyba że co innego wynika z ustawy. Konsekwencją tej regulacji jest zasada wyłączające płynące wody publiczne z obrotu cywilnoprawnego. Wyjątek od tej zasady musi wyraźnie wynikać z ustawy. Zatem płynące wody publiczne nie mogą być zbywane. Prawo wodne nie przewiduje też żadnego wyjątku dopuszczającego własność tych wód. Zatem w przypadku płynących wód publicznych nie ma możliwości nabycia ich własności i jedynym ich właścicielem jest Skarb Państwa.

Inaczej przedstawia się kwestia wód stojących oraz wód w rowach. Z art. 12 ustęp 1 Prawa wodnego wynika, że wody te stanowią własność właściciela nieruchomości. Konsekwencją tej normy jest dopuszczalność zbywania wód stojących oraz wód w rowach, ale jedynie wtedy, gdy jednocześnie zostaje przeniesiona własność nieruchomości - w tym przypadku nabycie własności odbywa się na zasadach ogólnych.

Analiza zagadnień własności wód wymaga również wspomnienia, iż istotne znaczenia dla zasięgu własności ma wyznaczenie linii brzegu. Za wody, będące przedmiotem regulacji prawa wodnego, mogę być uznane tylko te akweny, które mieszczą się w liniach brzegowych. Problematyka ta rejestrowana jest $\mathrm{w}$ art. 15 Prawa wodnego w sposób precyzyjny. Ustalenie linii brzegowej przypomina postępowanie rozgraniczeniowe nieruchomości z tym, że w tym wypadku chodzi o rozgraniczenie od gruntu, a nie gruntów od gruntu. Wyznaczenie linii brzegowej odgrywa jednak najważniejszą rolę niż rozgraniczenie gruntu, a to z tego względu, że linia ta nie tylko odnosi się do stanu faktycznego, ale również z powodu zmiany stanu prawnego. To, co mieści się w liniach brzegowych, stanowi przedmiot regulacji prawa wodnego, natomiast to, co znajduje się poza liniami brzegowymi, jest przedmiotem regulacji prawa cywilnego, a jedynie częściowo grunty sąsiadujące $\mathrm{z}$ wodami są przedmiotem regulacji prawa wodnego.

Podsumowując, należy zauważyć, że własność wód jest konstrukcją specyficzną, różniącą się od pojęcia własności w prawie cywilnym. Podstawowym elementem odróżniającym 
te rodzaje własności jest okoliczność, iż woda nie jest rzeczą $\mathrm{z}$ uwagi na jej niewyodrębnienie z przyrody. Pomimo braku tej cechy prawodawca zdecydował się jednak na konstrukcje własności wód, mając przede wszystkim na względzie więź wiążącą właściciela wód z wodą. Więź ta polega bowiem na najszerszym władztwie właściciela nad wodą, a owo najszersze władztwo obejmuje najszerszy zakres uprawnień. Jednocześnie z własnością wód ściśle wiążą się obowiązki właściciela, lecz nie należą one do istoty prawa własności. Te okoliczności zdecydowały, moim zdaniem, o tym, że prawodawca zdecydował się na konstrukcje własności wód, pomimo iż wody nie są rzeczami w rozumieniu prawa cywilnego. Własność wód jest też kategorią pojęciową wewnętrznie zróżnicowaną. Inaczej bowiem kształtuje się własność wód powierzchniowych, a inaczej wód podziemnych. Odrębnie ustawodawca reguluje własność wód płynących, a odrębnie wód stojących. Dla konstrukcji własności wód znaczenia ma również podział wód na wody publiczne i na wody niepubliczne.

Najistotniejszym podziałem z punktu widzenia własności wód jest podział na wody płynące i wody stojące. Właścicielem tych pierwszych może być tylko Skarb Państwa, a własność wykonywana jest wyłącznie w interesie publicznym. Ponadto wody płynące nie mogą być przedmiotem obrotu cywilnoprawnego, chyba że ustawa stanowi inaczej. Z kolei wody stojące mogą być przedmiotem własności innych podmiotów niż Skarb Państwa i w istocie stawią one przedmiot własności tego, kto jest właścicielem nieruchomości, na których te wody się znajdują. Mogą być one przedmiotem obrotu cywilnoprawnego, a na cele publiczne są wykorzystywane tylko wtedy, gdy są przedmiotem własności Skarbu Państwa lub jednostki samorządu terytorialnego albo gdy rada powiatu podejmie stosowaną uchwałę.

\section{BIBLIOGRAFIA}

Agopszowicz A., Wtasność wód, jej istota i charakter prawny, ZNUJ z 1974, z. 1.

Brzozowski A., Kocot W. J., Opalski W., Prawo rzeczowe. Zarys wykła$d u$, Warszawa 2012. 
Dybowski T. (red.), System Prawa Prywatnego, t. 3, Prawo rzeczowe, Warszawa 2003.

Dybowski T., Własność wód, [w:] S. M. Grzybowski (red.), Zagadnienia cywilistyczne prawa wodnego, Warszawa 1957.

Gniewek E., W kwestii statusu prawno rzeczowego powierzchniowych wód płynacych $i$ wspótwystępujących elementów naturalnych środowiska wodnego, ZNUW XXI.

Ignatowicz J., Stefaniuk K., Prawo rzeczowe, wyd. 4, Warszawa 2012.

Kobus-Ogrodniczak K. I., Korzystanie z wód - problemy prawne, Toruń 2011.

Pańko W., O prawie własności i jego wspótczesnych funkcjach, Katowice 1984.

Rotko J., Podstawy prawne gospodarki wodnej, Wrocław 2006.

Rudnicki S., O własności wód, NP. z 1982, z. 11-12.

Rudnicki S., Własność nieruchomości, wyd. 3, Warszawa 2012.

Stelmachowski A., Zarys teorii prawa cywilnego, Warszawa 1997.

Szachułowicz J., Prawo wodne. Komentarz, wyd. 4, Warszawa 2010.

Szewc A., Jyż G., Prawo własności przemysłowej, Warszawa 2003.

Kontakt e-mail:

kpos@umk.pl 